\title{
Present status of Aqua-medicines Used for Fish Culture at Shantahar and Adamdighi of Bogra District, Bangladesh
}

\author{
${ }^{1}$ Md. Kawsar Hossain, ${ }^{1}$ Muhammad Shahidul Haq, ${ }^{2}$ Binay Kumar \\ Chawkraborty, ${ }^{3} \mathrm{Md}$. Tawheed Hasan and ${ }^{4,5}$ Sabuj Kanti Mazumder \\ ${ }^{I}$ Department of Fisheries Management, Bangladesh Agricultural University, Mymensingh-2202, Bangladesh; \\ ${ }^{2}$ Department of Fisheries, Ministry of Fisheries and Livestock, Government of the People's Republic of \\ Bangladesh; \\ ${ }^{3}$ Department of Aquaculture, Sylhet Agricultural University, Sylhet-3100, Bangladesh; \\ ${ }^{4}$ Department of Aquatic Resource Management, Sylhet Agricultural University, Sylhet-3100, Bangladesh; \\ ${ }^{5}$ Marine Science Program, School of Environmental and Natural Resources Science, University Kebangsaan \\ Malaysia, Bangi, Selangor-43600.
}

\begin{abstract}
In order to investigate the present status of aqua-medicines used in various aquaculture activities in Bogra district, Bangladesh a survey was conducted with fish farmers and representative of pharmaceutical companies from December, 2011- to May, 2012 (180 days). The study showed that fish farmers were found to be used a wide range of aqua-medicines for aqua health management and for pond and water quality management . Zeo-fish, Zeo-prime, Ecolite, Megazeo plus etc. Tesmin, Emsen, Polgard, Virex are widely used toxic gas remover. Other than these, farmers were found to use several traditional aqua-medicines for aqua-health management, those included Potassium permanganate, Formalin, Salt, Lime, Melathion, Bleaching powder etc. Forty pharmaceutical companies have been recorded to market these products. Most of the products have been marketed from different countries like USA, Thailand, Malaysia, Belgium and China. Prices were variable, but seemed to be affordable by the aqua farmers. The present investigation pointed out several constraints associated with the use of such aqua-medicines, including lack of technical knowledge of farmers about use of aqua-medicines.
\end{abstract}

Key words: Aquaculture, antibiotic, disease, disinfectant, pond

\section{Introduction}

Aquaculture is one of the most important sectors which plays a significant role in the economy of Bangladesh in term of food, nutrition, income, employment and foreign exchange earnings. In Bangladesh aquaculture is rapidly spreading in recent years, but cannot fulfill the target production for many constraining factors. Fish disease is one of the most alarming factors. Aqua medicines are indeed essential ingredients to successfully managed the aquaculture, which has been forms for centuries ${ }^{[1]}$. Use of drugs for the management of aquaculture is widely recognized. These are essential components in pond construction, health management, soil and water management, enhancement of natural aquatic productivity, transportation of live organism, feed formulation, manipulation, enhancement of production, growth promotion and processing value enhancement of final product ${ }^{[2,3]}$.

There are several aqua-medicines were used in aquaculture for health management. These included sodium chloride, formalin, malachite green, methylene blue, potassium permanganate, glutaradehyde and tryfliralin ${ }^{[4,5,6,7]}$. Other popular traditional aqua-medicines included Zeolite, EDTA, Gypsum, Lime, Alum were used for the purpose of pond soil and water quality management. These are widely used to neutralize acidity, increase total alkalinity, increase hardness in the soil and water of grow out pond, reduce turbidity in ponds, chalets divalent and trivalent metal cations etc. Aquaculture in Bangladesh is expanding rapidly as well as trends of using more aqua-medicines in aqua-health management. Most of the farmers do not know the appropriate dosage and methods of application. It has been realized that farmers were using these aqua-medicines without knowing their efficacy. This is due to lack of information regarding the present status and consequences of aqua-medicines using in aqua-health management. Considering the above facts, the present study was conducted to identify new types of aqua-medicines used in aqua- health management; to know purpose of using, appropriate dosages and method of application of aqua-medicine and to identify the problems of using aquamedicine.

\subsection{Selection of the study area}

\section{Materials And Methods}

The study was conducted in two regions of Bogra district namely Shantahar and Adamdighi, Bangladesh (Figure 1) during the period of December 2011 to May 2012 (180 days). 


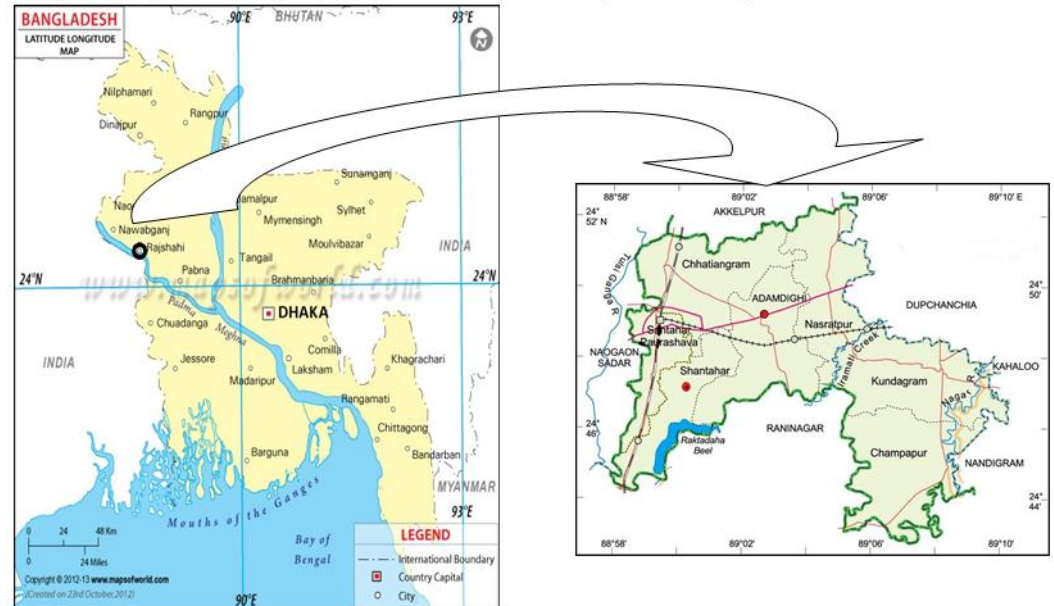

Figure 1. Maps indicating study areas. Closed circle and arrow denotes sampling site (Adamdighi and Shantahar $)^{[8]}$.

\subsection{Collection of data}

According to the objective of the study a questionnaire was prepared to collect the expected data. Data were collected from different target groups to have an overall picture of the aqua-medicines used in aquaculture activities in this area. Data were collected by direct interviews with farmers, representative of pharmaceutical companies and aqua-medicine seller. Each responded was given a brief introduction about the nature and purpose of the study during the interview. They were asked the questions systematically in a very simple manner with explanation and necessary information was recorded.

\subsection{Methodology}

From the list of huge number of new aqua-medicines found in market the first attempt was made to find out all those new product used by farmers in the different aspects of their need as for water quality management, disinfectant, toxic gas reducer, stress remover and as immunity increaser. All attempts were made to find out the popular aqua-medicines for aquaculture health management in field level. And finally aquamedicine producing pharmaceutical companies were enlisted in the investigation report.

\subsection{Data analysis}

The data were analyzed using tabular and descriptive statistical techniques. The summary tables were prepared in accordance to the objective of the study. The technique of analysis included the classification of tables into meaningful by arithmetic mean, percentage and ratios.

\section{Results}

\subsection{Different types of aqua-medicines: benefits and their mode of action}

Aquaculture in Bangladesh is increasing rapidly. For sustainable production different types of aquamedicines were found to be used at different stages of aquatic animal health management as growth promoter, oxygen supplying supporter, disinfectants, immunity increaser, toxic gas remover, stress remover and antibiotics for disease treatment.

\section{2 Available new zeolite in market and field level: Benefits and mode of action}

A wide range of aqua-medicines were seen to be used during pond preparation and water quality management by the farmers (Table 1). Among them Zeo-Fresh, Zeo Prime, Ecolite, Megazeo plus were widely used in field level. The active ingredients of such aqua-medicines are $\mathrm{SiO}_{2}, \mathrm{Al}_{2} \mathrm{O}_{2}, \mathrm{Fe}_{2} \mathrm{O}_{3}, \mathrm{CaO}, \mathrm{Na}_{2} \mathrm{O}$ etc. They use these for controlling water \& soil $\mathrm{pH}$, absorbing $\mathrm{NH} 3, \mathrm{H} 2 \mathrm{~S}$ and other noxious toxic substance, controlling growth of plankton, increasing resistance towards disease, ensuring bio-security, increasing dissolve oxygen, controlling water color and removing turbidity. 
Table 1: Zeolites: For pond and water quality management.

\begin{tabular}{|c|c|c|c|c|c|}
\hline Sl. No. & Name & Name & Active ingredient & Dosage & Price (Tk.) \\
\hline 1 & Zeo Fresh & Square & $\mathrm{SiO}_{2}, \mathrm{Al}_{2} \mathrm{O}_{3}, \mathrm{Fe}_{2} \mathrm{O}_{3} \mathrm{CaO}, \mathrm{MgO}, \mathrm{Na}_{2} \mathrm{O}, \mathrm{LOI}$ & $24 \mathrm{Kg} / \mathrm{acre}$ & $40 / \mathrm{Kg}$ \\
\hline 2 & Zeolite Gold & Fish tech & $\mathrm{SiO}_{2}, \mathrm{Al}_{2} \mathrm{O}_{3}, \mathrm{Fe}_{2} \mathrm{O}_{3} \mathrm{CaO}, \mathrm{MgO}, \mathrm{Na}_{2} \mathrm{O}$ & $400-500 \mathrm{~g} / \mathrm{dm}$ & $50 / \mathrm{Kg}$ \\
\hline 3 & Aqualite & Century & $\begin{array}{l}\mathrm{SiO}_{2}, \mathrm{Al}_{2} \mathrm{O}_{3}, \mathrm{Fe}_{2} \mathrm{O}_{3} \mathrm{CaO}, \mathrm{MgO}, \mathrm{Na}_{2} \mathrm{O}, \mathrm{K}_{2} \mathrm{O} \text {, } \\
\mathrm{TiO}_{2}\end{array}$ & $20-25 \mathrm{Kg} /$ acre & $50 / \mathrm{Kg}$ \\
\hline 4 & Pond lite & & $\mathrm{SiO}_{2}, \mathrm{Al}_{2} \mathrm{O}_{3}, \mathrm{Fe}_{2} \mathrm{O}_{3} \mathrm{CaO}, \mathrm{MgO}, \mathrm{Na}_{2} \mathrm{O}$ & $20-30 \mathrm{Kg} /$ acre & $50 / \mathrm{Kg}$ \\
\hline 5 & Ecolite & Eon & $\begin{array}{l}\mathrm{SiO}_{2}, \mathrm{Al}_{2} \mathrm{O}_{3}, \mathrm{Fe}_{2} \mathrm{O}_{3} \mathrm{CaO}, \mathrm{MgO}, \mathrm{Na}_{2} \mathrm{O}, \mathrm{K}_{2} \mathrm{O} \\
\mathrm{Mn}, \mathrm{P}\end{array}$ & $7 \mathrm{Kg} / 33 \mathrm{dm}$ & $50 / \mathrm{Kg}$ \\
\hline 6 & Zeo prime & $\mathrm{SK}+\mathrm{F}$ & $\begin{array}{l}\mathrm{SiO}_{2}, \mathrm{Al}_{2} \mathrm{O}_{3}, \mathrm{Fe}_{2} \mathrm{O}_{3} \mathrm{CaO}, \mathrm{MgO}, \mathrm{Na}_{2} \mathrm{O}, \mathrm{TiO}_{2}, \\
\mathrm{~K}_{2} \mathrm{O}\end{array}$ & $6-8 \mathrm{Kg} / 33 \mathrm{dm}$ & $50 / \mathrm{Kg}$ \\
\hline 7 & Geotox & Novartis & $\mathrm{SiO}_{2}, \mathrm{Al}_{2} \mathrm{O}_{3}, \mathrm{Fe}_{2} \mathrm{O}_{3} \mathrm{CaO}, \mathrm{MgO}, \mathrm{Na} 2 \mathrm{O}$ & $20-25 \mathrm{Kg} / 100 \mathrm{dm}$ & $55 / \mathrm{Kg}$ \\
\hline 8 & $\begin{array}{l}\text { Mega } \\
\text { Plus }\end{array}$ & ACI & $\begin{array}{l}\mathrm{SiO}_{2}, \mathrm{Al}_{2} \mathrm{O}_{3}, \mathrm{Fe}_{2} \mathrm{O}_{3} \mathrm{CaO}, \mathrm{MgO}, \mathrm{Na}_{2} \mathrm{O}, \mathrm{K}_{2} \mathrm{O}, \\
\mathrm{Mn}\end{array}$ & $25 \mathrm{Kg} / 100$ & $50 / \mathrm{Kg}$ \\
\hline
\end{tabular}

The mixture of $\mathrm{SiO}_{2}, \mathrm{Al}_{2} \mathrm{O}_{3}, \mathrm{Al}_{2} \mathrm{O}_{3}, \mathrm{CaO}$ etc. which together form minute pore and sponge like structure. Different types of toxic gases like $\mathrm{NH}_{3}, \mathrm{H}_{2} \mathrm{~S}$ and harmful pathogen become trapped in the pore of such compounds.

\subsection{Available new disinfectants in market and field level: benefits and mode of action}

Disinfectants are very important and widely used by the farmers (Table 2). The most popular disinfectants are Timsen, Emsen, Virex, Aquakleen etc. The benefits of disinfectants are to prevent different types of bacterial, fungal and viral diseases like gill rot, tail rot, dropsy etc. to maintain hygienic condition in hatchery equipment $\&$ floors and in some cases use to treat disease.

Table 2. List of available new disinfectant in market and field level.

\begin{tabular}{|c|c|c|c|c|c|}
\hline $\begin{array}{l}\text { Sl. } \\
\text { No. }\end{array}$ & Trade Name & Company & Active ingredient & Dosage & Price (Tk.) \\
\hline 1 & Polgard & Fish Tech BD & $\begin{array}{l}3 \text { methyl, } 4 \text { Alkyl two chain brominated } \\
\text { compounds }\end{array}$ & $500 \mathrm{ml} /$ acre & $200 / 200 \mathrm{ml}$ \\
\hline 2 & Virex & ACI & Potasium peroximono sulphate $50 \%$ & $100-150 \mathrm{~g} / 33 \mathrm{dec}$ & $400 / 100 \mathrm{~g}$ \\
\hline 3 & Virofore & & Iodine $2.8 \%$ & $100 \mathrm{ml} / 33 \mathrm{dec}$ & $100 / 100 \mathrm{ml}$ \\
\hline 4 & Aquakleen & Square & $\begin{array}{l}\text { Tetradesail Tri-methyl Amonium bromid, } \\
\text { BKC }\end{array}$ & $0.5-11 /$ acre & $300 / 1$ \\
\hline 5 & Timsen & Eon & $\begin{array}{l}\text { n-alkyl dimethyl benzyl ammonium } \\
\text { chloride+ stabilized urea }\end{array}$ & $\begin{array}{l}20 \mathrm{~g} / 33 \mathrm{dec} \text { (For prevention) } \\
80 \mathrm{~g} / 33 \mathrm{dec} \text { (For Treatment) }\end{array}$ & $260 / 50 \mathrm{~g}$ \\
\hline 6 & Emsen & Ethical & $\begin{array}{l}\text { n-alkyl dimethyl benzyl ammonium } \\
\text { chloride+ stabilized urea }\end{array}$ & $80 \mathrm{~g} / 33 \mathrm{dec}$ & $255 / 50 \mathrm{~g}$ \\
\hline
\end{tabular}

\subsection{Available new toxic gas reducer in market and field level: benefits and mode of action}

Several aqua-medicines were found in the aqua-medicines shops that were reported to be used as toxic gas reducer (Table 3). The available toxic gas reducer were gastrap, gas stop, gasonex plus, ammonil. The active ingredients of such medicines were mainly sodium lorile ether sulphate, aluminum hydroxide, silicon di oxide, bacillus subtilis, lactic acid etc. The price found to be quite affordabe by the commercial aqua farmers. Benefits of using toxic gas reducer are to remove the toxic gas like $\mathrm{NH}_{3}, \mathrm{H}_{2} \mathrm{~S}, \mathrm{CO}_{2}$, etc. from the bottom of pond, to reduce concentration of ammonia and to remove off odor of water and create hygienic condition in pond.

Table 3. List of available toxic gas reducer in market and field level.

\begin{tabular}{|c|c|c|c|c|c|}
\hline $\begin{array}{l}\text { Sl. } \\
\text { No. }\end{array}$ & Trade Name & Company & Active ingredient & Dosage & Price (Tk.) \\
\hline 1 & Gastrap & $\begin{array}{l}\text { Square pharmaceuticals Co } \\
\text { Ltd. }\end{array}$ & $\begin{array}{l}\text { Lactic acid Bacillus sp. Bacillus } \\
\text { subtillis } \\
\text { Cellulase, Hemicellulase, amylase }\end{array}$ & $200 \mathrm{mg} / \mathrm{acre}$ & $3000 / \mathrm{Kg}$ \\
\hline 2 & Gas stop & $\begin{array}{l}\text { Organic pharmaceuticals Co. } \\
\text { Ltd.(BD) Co. Ltd. }\end{array}$ & Bacillus subtillis $\mathrm{Al}_{2} \mathrm{O}_{3} \quad \mathrm{SiO}_{2}$ & $500 \mathrm{mg} / \mathrm{acre}, 3$ weeks & $2500 / \mathrm{Kg}$ \\
\hline 3 & Gasonex plus & Fish tech. (BD) Co. Ltd. & Na-lorile ether sulphate & 200-400 mg/Kg Zeolite & $2950 / \mathrm{Kg}$ \\
\hline 4 & Pond D tox & Fish tech.(BD) Co. Ltd. & Pracoccus pantotrophus & $4 \mathrm{ppm}$ & $2800 / \mathrm{Kg}$ \\
\hline 5 & Aqua Magic & Fish tech.(BD) Co. Ltd. & $\begin{array}{l}\text { Azotabactor chorococcum, Bacillus } \\
\text { subtillis, candida utilis }\end{array}$ & $\begin{array}{l}5 \mathrm{Kg}+100 \mathrm{~g} \text { sugar }+250 \mathrm{~g} \text { rice } \\
\text { bran mixed with } 10 \text { liter water }\end{array}$ & $2700 / \mathrm{kg}$ \\
\hline 6 & Ammonil & $\begin{array}{l}\text { Noverties Pharmaceuticals Co. } \\
\text { Ltd. }\end{array}$ & $\begin{array}{l}\text { Yucca plant extract, Bacillus subtillis, } \\
\text { candida utilis }\end{array}$ & $100-200 \mathrm{~g} / \mathrm{acre}$ & $2800 / \mathrm{kg}$ \\
\hline 7 & Bio-Aqua-50 & Eon animal health Co. Ltd. & Yucca plant extract, Saponin & $60-70 \mathrm{ml} / 33 \mathrm{dm}$ & $2900 / \mathrm{kg}$ \\
\hline
\end{tabular}




\subsection{Available new stress remover in market and field level: benefits and mode of action}

Several aqua-medicines were found in the market using as stress remover (Table 4). The available stress remover were cevit aqua, ossi-c, osmosaline, aqua-c etc. The active ingredients of such medicines were mainly 1-ascorbic acid (Vit-C), oxolinic acid, bitaglucan(Vit-C), calcium $80 \mathrm{mg}$ (Vit-C) 200mg, ascorbic acid 50 $\mathrm{g}$ (Vit-C), natural betain. Benefits of using remover are for instant relief from any stress (transportation, over density heat shock, adverse environmental condition), for healing of wound and ulcers, for improving disease resistance, for reducing cannibalism and mortality, and fish becomes more active.

Table 4. List of available stress remover in market and field level.

\begin{tabular}{|c|c|c|c|c|c|}
\hline $\begin{array}{l}\text { Sl. } \\
\text { No. }\end{array}$ & Name & Company & Active ingredient & Dosage & Price \\
\hline 1 & $\begin{array}{l}\text { Cevit } \\
\text { Aqua }\end{array}$ & $\begin{array}{l}\text { Square pharmaceutical Co. } \\
\text { Ltd. }\end{array}$ & L-ascorbic acid (Vit-C) & $\begin{array}{l}\text { For hatchery } 0.5-2 \mathrm{~g} / \mathrm{t} \text { water, For pond } 2-3 \\
\mathrm{~g} / \text { Kg feed }\end{array}$ & $2000 / \mathrm{Kg}$ \\
\hline 2 & Ossi-C & Fish Tech (BD) Co. Ltd. & $\begin{array}{l}\text { Oxolinic acid, Bitaglucan } \\
\text { (Vit-C) }\end{array}$ & For $4-5 \mathrm{~g} / \mathrm{Kg}$ feed & $1800 / \mathrm{Kg}$ \\
\hline 3 & $\begin{array}{l}\text { Aqua } \\
\text { Cal-C }\end{array}$ & $\begin{array}{l}\text { ACI pharmaceutical Co. } \\
\text { Ltd. }\end{array}$ & $\begin{array}{l}\text { Calcium 80mg (Vit-C ) } \\
200 \mathrm{mg}\end{array}$ & $1 \mathrm{Kg} / \mathrm{Kg}$ feed & $1900 / \mathrm{Kg}$ \\
\hline 4 & Aqua-C & $\begin{array}{l}\text { ACI pharmaceutical Co. } \\
\text { Ltd. }\end{array}$ & $\begin{array}{l}\text { Ascorbic acid } 50 \mathrm{~g} \text { (Vit- } \\
\text { C) }\end{array}$ & $0.1-0.3 \mathrm{~g} / \mathrm{Kg}$ feed & $1700 / \mathrm{Kg}$ \\
\hline 5 & $\begin{array}{l}\text { Glucovet- } \\
\text { Premix }\end{array}$ & $\begin{array}{l}\text { ACME pharmaceutical Co. } \\
\text { Ltd. }\end{array}$ & Vit-C & 1-2 g/liter water & $2000 / \mathrm{Kg}$ \\
\hline 6 & $\begin{array}{l}\text { Osmosalin } \\
\mathrm{e}\end{array}$ & Eon Animal health Co. Ltd. & Natural Betain & $1-2 \mathrm{~g} / 5-10$ liter water & $1800 / \mathrm{Kg}$ \\
\hline
\end{tabular}

\subsection{Available new immunity increaser in market and field level: benefits and mode of action}

Several aqua-medicines were found in the aqua-medicine shops that were reported to be used as immunity increaser (Table-5). The available immunity increaser were resistol, charger gel, aqua cell etc. the active ingredients of such medicines were mainly Vit-C, Ca, P, Amino Nitrogen, Betain, 1-3 Glucan, Polysaccharix, Oligshacharix. Benefits of using immunity increaser are to prevent disease, provide boost immunity and reduce stress, increase survival rate, and to improve resistant towards disease.

Table 5. List of available immunity increaser in market and field level.

\begin{tabular}{cllllc}
\hline $\begin{array}{c}\text { Sl. } \\
\text { No. }\end{array}$ & \multicolumn{1}{c}{ Name } & \multicolumn{1}{c}{ Company } & \multicolumn{1}{c}{ Active ingredient } & Dosage & Price(Tk) \\
\hline 1 & Resistol & Square & Vit-C, Ca, P, Amino Nitrogen, Betain & $5 \mathrm{ml} / \mathrm{Kg}$ feed & $1150 / \mathrm{l}$ \\
2 & Charger gel & Fish Tech & 1-3 D-Glucan, Polysscharides, Betaglucans & $2-4 \mathrm{~g} / \mathrm{Kg}$ feed & $1200 / 1$ \\
3 & Ossi-C & Fish Tech & Oxolinic acid Bitaglucan, Vit-C & $4-5 \mathrm{~g} / \mathrm{Kg}$ feed & $1100 / 1$ \\
4 & Aqu cell & ACI & Ca, P, Vit D3, habrs & $1-2 \mathrm{~g} / \mathrm{Kg}$ feed & $1000 / 1$ \\
& & & & $0.05 \%-0.1 \%$ & $1100 / 1$ \\
\hline
\end{tabular}

\subsection{Problems associated with the use of aqua-medicines}

During the present study some problems were identified which are summarized below as 1 . aquamedicines may persists and retaining their biocidal properties in aquatic system for longer period; 2 . it may create problem for non-target species; 3 . over doses may create toxic problem; 4. major concern the use of antibiotics in aquaculture involve the development and transfer of drug resistance to pathogenic bacteria from farm animal to human; 5. lack of technical knowledge of fish farmers about the use of aqua-medicines; and 6. lack of knowledge of fish farmers about residual effect and withdrawal period of aqua-medicines. Use of drugs and popularization assessment and percentages stated Table 6 and Table 7.

Table 6. Popular aqua-medicines in field level in use.

\begin{tabular}{|c|c|c|c|c|c|}
\hline & Name & Company & $\begin{array}{c}\text { Number of farmers } \\
\text { Questioned }\end{array}$ & $\begin{array}{l}\text { Number of farmers responded } \\
\text { positively }\end{array}$ & $\begin{array}{c}\text { Percent farmers respondent } \\
\text { positively }\end{array}$ \\
\hline \multirow{4}{*}{  } & Zeo-fresh & Square & 20 & 5 & 25 \\
\hline & Zeo-prime & $\mathrm{SK}+\mathrm{F}$ & 20 & 5 & 25 \\
\hline & Mega-zeo plus & $\mathrm{ACI}$ & 20 & 5 & 25 \\
\hline & Zeo-lite gold & Fish tech & 20 & 5 & 25 \\
\hline \multirow{3}{*}{ 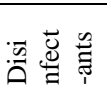 } & Timsen & Eon & 20 & 8 & 40 \\
\hline & Emsen & Ethical & 20 & 4 & 20 \\
\hline & Virex & $\mathrm{ACI}$ & 20 & 4 & 20 \\
\hline
\end{tabular}


Present status of Aqua-medicines Used for Fish Culture at Shantahar and Adamdighi of Bogra

\begin{tabular}{|c|c|c|c|c|c|}
\hline & Polgard & Fish tech & 20 & 3 & 15 \\
\hline \multirow{4}{*}{ 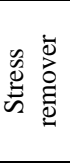 } & Cevit aqua & Square & 20 & 8 & 40 \\
\hline & Osmosaline & Eon & 20 & 5 & 25 \\
\hline & Aqua-C & ACI & 20 & 5 & 25 \\
\hline & Ossi-C & Fish tech & 20 & 2 & 10 \\
\hline \multirow{4}{*}{ 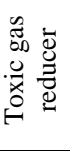 } & Gasonex plux & Fish tech & 20 & 7 & 35 \\
\hline & Ammonil & Novertis & 20 & 6 & 30 \\
\hline & Gas trap & Square & 20 & 4 & 20 \\
\hline & Bio-aqua 50 & Eon & 20 & 3 & 15 \\
\hline \multirow{3}{*}{  } & Resistol & Square & 20 & 9 & 45 \\
\hline & Aqua cell & $\mathrm{ACI}$ & 20 & 8 & 40 \\
\hline & Charger gel & Fish tech & 20 & 3 & 15 \\
\hline
\end{tabular}

Table 7. Number of products of different pharmaceutical companies.

\begin{tabular}{clcc}
\hline SI No. & & Company Name & Products (\%) \\
\hline 1 & Organic & 13 & 8.60 \\
2 & ACI & 18 & 12.00 \\
3 & Rals Agro & 12 & 8.00 \\
4 & Novartis & 7 & 4.66 \\
5 & Eon & 9 & 6.00 \\
6 & Fish Tech & 17 & 11.33 \\
7 & Square & 9 & 6.00 \\
8 & Advanced animal health & 12 & 5.33 \\
9 & The ACME & 46 & 8.00 \\
10 & Other 10 companies & & 30.08 \\
\hline
\end{tabular}

\section{Discussion}

Aquaculture has a significant role in the economy of Bangladesh. Over the last decade it has expanded diversified, intensified and technologically improved. The aquaculture activities in Bangladesh are influenced by a number of new aqua-medicines used for aqua-health management. The present study noticed a wide range of new aqua-medicines that were being marketed by various companies for aqua-health management. Fish health management and disease treatment were major area where farmers were seen to be used a lot of such aqua-medicines. EUS, tail rot, fin rot, red rot, white spot and dropsy were the major diseases found in studied areas. A number of authors also reported the similar conditions in aquaculture of Bangladesh ${ }^{[7,9,10,11]}$.

The present investigation showed that a wide range of new aqua-medicines that were being marked by various trade names which included Resistol, Ossi-C, Charger Gel, Cevit Aqua, Osmosaline, Gastrap, Gas stop etc. were widely used by the farmers for aqua-health management in field level. Farmers were also seen to be used several traditional aqua-medicines in aqua- health management included lime, salt, potassium permanganate, melathion, sumithion, formalin, rotenone etc. which is similar to the previous studies reported in aquaculture of Bangladesh ${ }^{[5,7,11]}$. Farmers were seen to be used antibiotics for bacterial disease treatment. Most of the farmers do not follow the appropriate dosage during disease treatment. It is widely recognized the excessive use of antibiotics contributes the development of resistant strain of bacteria ${ }^{[12]}$.

At present 150 products of 40 animal health companies were seen to market and field level. Some aqua-medicines were found only trade names. Neither farmers nor seller did not have clear idea about the activate ingredient and method of application of the particular aqua-medicines though they were using those without hesitation. Only few companies provide details product profile to the farmers. It was found that same product of different companies were variable dosage. The pharmaceutical companies should take care about those products.

Most of the farmers were seen to be used antibiotics for bacterial diseases treatments indiscriminately. Some farmers were not following the described dosages for treatment. It is widely recognized that the excessive use of antibiotics contribute the development of resistant strains of bacteria ${ }^{[12]}$. Therefore, it is important to follow the recommended dosages and method of application especially in the case of antibiotics.

Aquaculture is gradually a common practices in Bangladesh. Disease treatment in aquaculture can be a great value when used properly but when improperly applied can causes great loses of aquatic ecosystem. So, it is important to apply proper disease and best application methods for aqua-health management. Pharmaceuticals 
companies should conduct more research and development towards reducing the harmful impact of aquamedicine in aquaculture.

\section{Conclusion}

The investigation was conducted to know the present condition of aqua-medicine used in aqua-health management. Management is the main thing for having any production. Without proper management, it is really unexpected from aqua-culture to have production. Disease problem is an alarming factor for fish culture. Indeed aqua-medicines are essential components to avoid this problem. But excessive use of aqua-medicine is harmful for aquatic ecosystem. The present study on aqua-medicine pointed out some problems of using aqua-medicines. Unfortunately little attention has been paid on the documentation of aqua-medicines. As a result, there is a lack of information regarding the impact of those aqua-medicines. However, respective authority, policy maker, scientist and researcher should work together to reduce the negative impact of aqua-medicines.

\section{References}

[1]. R.P. Subasighe, U. Barg and A. Tacon, Chemicals in Asian aquaculture: need, usage, issues and challenges, in J.R. Arthur, C.R. Lavilla-Pitogo, R.P. Subasinghe (Eds), Use of Chemicals in Aquaculture in Asia, (Southeast Asian Fisheries Development Center, Aquaculture Department tigbauan, Iloilo, Philippines, 1996) 1-6.

[2]. H. Alderman, P.A. Chiappori, and L. Haddad, Unitary versus Collective Models of the Household: Time to Shift the Burden of Proof? DELTA Working Papers, 1994, 94-17, DELTA (Ecole normale supérieure).

[3]. GESAMP. (IMO/FAO/UNESCO/IOC/WMOAVHO/IAEA/UN/UNEP Joint Group of Experts on the Scientific Aspects of Marine Environmental Protection), 1997, Reducing environmental impacts of coastal aquaculture. Rep. Stud-GESAMP, 47, 35pp.

[4]. J.A. Plumb, Disease control in aquaculture, in I.M. Shariff, R.P. Subasinghe and J.R. Arthur (Eds.), Disease in Asian Aquaculture, (Fish Health Section of the Asian Fisheries Society, Manila, Philippines, 1992) 3-17.

[5]. M. Phillips, The use of chemicals in carp and shrimp aquaculture in Bangladesh, Cambodia, Lao PDR, Nepal, Pakistan, Sri Lanka and Vietnum, in J.R. Arthur, C.R. Lavilla-Pitogo, R.P. Subasighe (Eds), Use of Chemicals in Aquaculture in Asia, (Southeast Asian Fisheries Development Centre, Aquaculture Department Tigbauan, Iloilo, Philippines, 1996) 75-84.

[6]. M.R. Hasan, and G.U. Ahmed, Issues in carp hatcheries and nurseries in Bangladesh, with special reference to health management, in J.R. Arthur, M.J. Phillips, R.P. Subasinghe. M.B. reantaso and L.H. MacRae (Eds), (primary Animal Health Care in Rural, smallscale. Aquaculture Development. FAO Fish. Tech. Pap.No. 406, 2002) 147-164.

[7]. DoF, Fish Fortnight Compendium, Department of Fisheries, Matsha Bhaban, Dhaka, 2002, 44-45 pp.

[8]. www.mapsofworld.com

[9]. M.N. Amin, Impact of fish diseases on fish culture in northern region of Bangladesh, Rural Development Academy, Bogra, Bangladesh, 2000, $28 \mathrm{pp}$.

[10]. M.A. Mazid, Fsh Disease and Prevention, Bangladesh Fisheries Research Institute, Mymensingh, 2001,36 pp.

[11]. M.A.R. Faruq, M.J. Alam, M.M.R. Sarkar, and M.B. Kabir, Statue of fish disease and health management practices in rural freshwater aquaculture activities in Mymensingh area, Bangladesh, Bangladesh Journal of Fisheries, 2004, 29(1-2), 1-10.

[12]. V. Inglis, Antibacterial chemotherapy in aquaculture: review of practice, associated risks and need for action, in Use of Chemicals in Aquaculture. 1996. 